Malgorzata BUDZOWSKA

Uniwersytet Łódzki
Jadwiga CZERWIŃSKA

Uniwersytet Łódzki

\title{
INTERSEMIOTYCZNY PRZEKLAD MITU ANTYCZNEGO W SPEKTAKLU „FEDRA” MAI KLECZEWSKIEJ ${ }^{1}$
}

\section{INTERSEMIOTIC TRANSLATION OF ANCIENT MYTH IN THE PRODUCTION OF PHAEDRA BY MAJA KLECZEWSKA}

The present paper tends to analyze the procedure of intersemiotic translation of ancient myth of Phaedra, in its written version by Euripides (Hippolytus), into the contemporary stage production of Phaedra by Maja Kleczewska. The analysis of the performance is preceded by the extended introduction regarding reception of myth in general, and reception of Phaedra myth in particular. In this context, theories of Hans Blumenberg and Gilbert Durand are recalled in order to establish the understanding of myth's transformation. Myth of Phaedra is scrutinized diachronically and synchronically within the background of Maurice Merleau-Ponty's idea of body and sexuality. The theatre production is explored with reference to its textual basis (Euripides, Seneca, Tasnádi, Enquist) on the one hand, and in relation to the contemporary theories of actor's body (Erika Fischer-Lichte, Hans-Thies Lehmann). The overarching goal of the paper is to analyze the procedure of intersemiotic translation of the mythical core of Phaedra myth (defined in terms of body) into actor's body on stage (defined in its phenomenology).

Keywords: myth of Phaedra, reception, semiotics, body, actor, theatre, Kleczewska

\footnotetext{
${ }^{1}$ Artykuł przedstawia wyniki badań prowadzonych w ramach projektu Recepcja mitów antycznych z kręgu kultury śródziemnomorskiej $w$ teatrze polskim XXI wieku finansowanego z program SONATA Narodowego Centrum Nauki (DEC-2012/07/D/HS2/01106) i został już opublikowany w wersji angielskiej: Budzowska\&Czerwińska 2015. Część z rozważanych tu zagadnień została przedstawiona w książce Budzowska 2017.
} 
Ciało może symbolizować egzystencję właśnie dlatego, że ją urzeczywistnia $i$ że jest jej aktualnościa ${ }^{2}$.

\section{Wprowadzenie}

Natura dramatu konstytuuje się poprzez dialektyczne napięcie między językiem a przedstawieniem, pomiędzy tekstem a jego sceniczną implementacją. Ten dynamiczny interfejs zostaje zainicjowany poprzez rozważenie sprawczości języka w odniesieniu do warunków sceny (Worthen 2013: 82-83). Ślady teatralnego alter ego dramatu mogą być łatwo zauważone w tekście literackim, ponieważ ma on naturę dialogową i zawiera didaskalia. W tym kontekście dramat antyczny winien być traktowany w sposób szczególny, zważywszy na fakt, iż w swojej oryginalnej wersji nigdy nie zawierał wskazówek scenicznych. Taka sytuacja wynikała ze starożytnej praktyki teatralnej, gdzie autor sztuki był jednocześnie jej inscenizatorem, a sam tekst był tworzony nie dla czytelnika, lecz dla widza ${ }^{3}$.

W odniesieniu do wyżej omówionych okoliczności, współczesne inscenizacje dramatów antycznych powszechnie bazują na przekładach zawierających wskazówki sceniczne formułowane przez tłumacza lub wydawcę, a nie przez autora. Należy mieć jednak na uwadze fakt, iż współczesne sceniczne implementacje dramatów antycznych rzadko kiedy mają naturę zerojedynkową zgodną z ideą nihil in gestu nisi in verbis. W takim podejściu do tekstu inscenizatorzy tworzą własne dramatyczne narracje dla fabuły mitycznej, starając się przełożyć symboliczne znaki tekstu pisanego na audiowizualne i kinetyczne znaki sceny. Rozważając zjawisko „inscenizacji klasyki”, w tym klasyki starożytnej, Patrice Pavis podjął się kategoryzacji sposobów scenicznej translacji dramatów klasycznych (2011:278-284). W tym kontekście spektakl Fedra Mai Kleczewskiej (2006, Teatr Narodowy w Warszawie), który adaptuje dla sceny jeden z najstarszych i najbardziej kontrowersyjnych mitów greckich, może być definiowany jako projekt „powrotu do mitu” jako, że, zgodnie z aktualnymi trendami inscenizacyjnymi, Kleczewska wydaje się inscenizować nie tyle tekstowe wersje mitu, ale sam mit sensu stricto.

Mimo to, jak wskazuje sama reżyserka, jej spektakl odwołuje się do czterech sztuk adaptujących mit Fedry: do starogreckiego dramatu Eurypidesa pt. Hipolit

${ }^{2}$ Merleau-Ponty 2001: 185.

3 Sytuacja taka była powszechna w starożytnym teatrze greckim, gdzie spisywaniem dramatów zajęto się dopiero na przełomie okresu klasycznego i hellenistycznego. Nieco odmienna sytuacja miała miejsce w teatrze rzymskim, który szeroko czerpał ze spuścizny literackiej (dramatycznej) Grecji. Mimo to, dramaty nadal pisane były przede wszystkim dla sceny, w mniejszym stopniu dla lektury. Jakkolwiek, w odniesieniu do dramatów Seneki (jedynych zachowanych w całości tragedii rzymskich), nadal żywa, i chyba nierozstrzygalna, jest dyskusja, zainicjowana przez Augusta Wilhelma Schlegela, dotycząca kwestii, czy sztuki rzymskiego filozofa były tworzone wyłącznie do recytacji lub lektury, bez intencji ich inscenizacji. Cf. Wesołowska 1991. 
uwieńczony, uznawanego w kręgu literaturoznawców za tekst źródłowy, do jego starożytnej łacińskiej wersji Seneki pt. Fedra oraz do dwóch dramatów współczesnych - Till Fedra (Dla Fedry, 1980) szwedzkiego dramatopisarza Pera Olova Enquista i Phaidra. Végsö Aktus (Fedra. Ostatni akt $\left.{ }^{4}, 2005\right)$ węgierskiego poety Istvána Tasnádiego. Ten intertekstualny background jednoznacznie wskazuje, że reżyserka nie zamierza wiernie odtwarzać litery tekstu, lecz dąży do szerszej refleksji nad istotą mitu poprzez krytyczną analizę dyskursu literackiego zawiązującego się wokół mitu. Taka formuła kreatywnego działania artysty w odniesieniu do spektaklu Kleczewskiej jest zasadniczą kwestią omawianą w tym artykule. Prezentowany tutaj schemat interpretacji jest jednocześnie próbą odzwierciedlenia procesu twórczego reżyserki, dlatego analiza inscenizacji będzie przeprowadzona w kontekście kreatywnej mitokrytyki z odniesieniami do literackich wersji mitu wskazywanych przez Kleczewską. Tak ujęte przestrzenie refleksji mają na celu skrupulatne badanie zjawiska translacji intertekstualnej mitu w powiązaniu z krytyczną obserwacją intersemiotycznego interfejsu pomiędzy dyskursem literackim i jego cielesną transformacją na scenie ${ }^{5}$.

\section{Sensotwórcza praca mitu}

Zgodnie z teorią Hansa Blumenberga (2009), mit ma naturę sensotwórczą i jest sposobem uzyskiwania i zachowywania dystansu (Bedeutsamkeit) do tych zjawisk, które są trudne do rozpoznania i nazwania przez rozum ludzki. To spostrzeżenie Blumenberg rozwija w teorię dramatu, wedle której antyczna forma tragedii odzwierciedlała model zdystansowanej refleksji nad tymi zjawiskami. Dlatego też dramat antyczny w jego wersji scenicznej stanowił dla publiczności moment kontemplacji litości i trwogi w bezpiecznym środowisku teatru.

W najczystszej formie bycie obserwatorem z dystansu spotykamy w tragedii greckiej. Schemat patrzenia na widowisko jest prototypem teorii zachowującej element kontemplatywny

${ }^{4}$ Polski przekład tekstu Phaidra. Végső Aktus nosi tytuł Fedra fitness (Tasnádi 2000), jakkolwiek nie jest on tłumaczeniem tytułu oryginalnego, lecz inwencją własną tłumaczy.

${ }^{5}$ Cf. Sosień 2003: 12: „Zataczając koło, lub raczej wyznaczając dośrodkową spiralę, badacz ma możliwość dotknięcia sensu, bowiem otwiera się przed nim szansa dotarcia do jądra semantycznego badanego zjawiska. Jednakże doświadczenie owego 'punktu zerowego' pozostanie niepełne, jeśli ograniczy się do poziomu tekstu, a więc do zapisu, poddanego formalnej analizie strukturalnej czy semantycznej, z pominięciem obszarów należących do mitu." Powyższy cytat trafnie definiuje podejście badawcze reprezentowane w tym artykule. Kolażowa natura bazy tekstowej przedstawienia Kleczewskiej stanowi egzemplifikację typowo postmodernistycznej metody dialogu z tradycją. $C f$. też Eco 1981: 36 (thum. M.B.): „To nie oznacza, że tekst jest krystalicznie czystą strukturą interpretowalną w jeden określony sposób; przeciwnie, tekst jest leniwą maszyną, która zmusza swoich potencjalnych czytelników do wykonania części jego pracy tekstowej, ale modalności jego interpretacyjnych działań - jakkolwiek liczne i prawdopodobnie nieskończone - nie są bynajmniej nieokreślone i muszą być rozpoznane jako narzucone przez strategie semiotyczne proponowane przez tekst." 
w dystansie, który dzięki katharsis, poprzez lęk i litość, uwalniających widza, dziedziczy filozofia. Mit i racjonalność w dystansie próbują równolegle, często się przecinając, usuwać zbudzone bynajmniej nie z powodu snu rozumu, upiory. (Klemczak 2005: 54)

W takim ujęciu, abstrahując od wszelkich kontekstów religijnych, mit staje się dynamiczną siłą wyobraźni - imaginaire en devenir. Pozostając nieustannie in statu nascendi, plasuje się w perspektywie „pretekstu” (Sosień 2003: 13), którego mitemy ${ }^{6}$ są jednak rozproszone $\mathrm{z}$ uwagi na jego wielowariantowość. Dlatego zrozumienie mitu jest możliwe jako terminus ad quem (Klemczak 2005: 54), czyli jako moment zakończenia pracy mitu w jego poszczególnych wersjach. Mimo, iż mit jest agregatem wszystkich swoich wersji, nigdy nie osiąga ostatecznego kresu (i sensu), pozostając otwarty na różnorodne konfiguracje mitemów i ich znaczeń. Mity, według Gilberta Duranda (1979), są obserwowalne poprzez różnicującą powtarzalność swoich własnych wersjī, a badanie tak rozumianej dynamiki mitu łączy się ze śledzeniem jego zmian tożsamościowych ${ }^{8}$.

Jak trafnie zauważa Fritz Graf, ,dobrze znane trudności, jakie są napotykane w poszukiwaniu definicji mitu, która jest bliska każdej kulturze, współczesnej i przeszłej, i która może być zaakceptowana przez każdą grupę badaczy, potwierdzają przypuszczenie, że globalna jednorodność jest bardziej hipotezą heurystyczną niż rzeczywistością" (Graf $2002^{9}$ ). Ponadto, w nawiązaniu do teorii mitu Makrobiusza, Graf wskazuje, że „mit (fabula) jest fikcją stworzoną przez autora, [zatem] jego powierzchnia narracyjna jest fałszywa, ale skrywa ona głęboką prawdę” (ibid.). Odnalezienie i ujawnienie tej „głębokiej prawdy" mitu poprzez jej ekspresję w systemie znakowym teatru jest istotą kreacji artystycznej, która bazując na wersjach literackich, używa narzędzi i znaków audiowizualnych.

${ }^{6}$ Mitem jest fonemem mitu, jego najmniejszą cząstką strukturalną. $C f$. Lévi-Strauss 1985; 1955.

Cf. Jasionowicz 2003: 26-27: „Redundancje, fluktuacje, przemiany czy nawet czasowy zanik pewnych form znaczących należą do tego samego, nieustannego, wielkiego procesu: procesu wytwarzania sensów."

${ }^{8}$ Najbardziej rozpoznawalną sygnaturą mitu jest imię bohatera mitycznego. Gdy bohater mityczny staje się postacią dzieła sztuki, przyjmuje nowe wcielenia, jego struktura dyspozycyjna osiąga nowe aktualizacje zgodne z kontekstem procesu twórczego. $C f$. Wachowski 1993: 65: „(...) bohater [mityczny] jest niejako zewnętrzny wobec literackich jego portretów, podobnie jak mit, istnieje w planie nadrzędnym. Zewnętrzność bohatera mitycznego w stosunku do jego 'odbicia', postaci dramatu, sprawia, że musi on być wyposażony w zespół cech niejako 'wysuniętych', indeksalnych, dzięki którym będzie mógł być rozpoznawalny i które umożliwią jego 'przemieszczanie' do konkretnych dzieł. Na warunki owej 'transmutacji', obok indeksalności, mają również wpływ cechy incydentalne, dodatkowe, niejako peryferyjne, które nie muszą być reprodukowane, lecz tworzą, wobec 'portretu podstawowego', swoiste zaplecze. [...] kolejne wersje [literackie] rozbudowują sferę indeksu i tak dalece przekształcają obraz mitu, że tworzą kilka równoległych jego wersji $[\ldots]$ ".

${ }^{9}$ http://www.maicar.com/GML/020Contributors/FGGenese.html [18.01.2015; thum. M.B]. 
W estetyce postmodernistycznej, w której omawiany spektakl jest głęboko zanurzony, jakiekolwiek odniesienia do schematów inwariantowych ${ }^{10}$ mitu są bezzasadne. Dla sztuki postmodernistycznej wszystkie wcześniej ustalone kanony, w tym kanoniczne korpusy wersji mitu, przestają być nietykalnymi konstruktami. Jakkolwiek licentia poetica twórcy musi mieć na uwadze zachowanie chociaż minimalnego zarysu sygnatury mitycznej, o ile zakłada intencjonalny gest ku lekturze rozpoznającej. Przyjemność odbiorcy zasadza się bowiem w dużej mierze na konfrontacji dobrze znanych indeksów bohatera mitycznego lub fabuły mitycznej z ich nowymi aktualizacjami. Doświadczenie intertekstualności znajduje swoją przyjemność w „różnicującej powtarzalności” poszczególnych tekstów, w pluralistycznej naturze lektury, która ewokuje nieustanne napięcie w poszukiwaniu sensów.

\section{Intertekstualna tożsamość mitu i jej sceniczne ucieleśnienie}

Fedra Mai Kleczewskiej bazuje na tekstach antycznych Eurypidesa i Seneki, inicjujących serię tematyczną mitu, zestawionych z postmodernistycznymi sztukami Enquista i Tasnádiego, które konstytuują najbardziej aktualne termini ad quem, momenty, w których mit osiąga kontekst najbliższy współczesnemu odbiorcy. Taka kompozycja „wybranych egzemplifikacji”"11 mitu wydaje się być intencjonalnym działaniem reżyserki, która jednocześnie ujawnia wstępne założenia inscenizacji. Zestawienie początku i aktualnego końca serii może być również rozważane jako procedura integrująca konteksty i znaczenia diachronicznie od siebie odległe, lecz mające potencjał tworzenia jakości synchronicznych. Hipotetycznie możemy założyć, że najistotniejszą jakością synchroniczną rozpoznawalną we wszystkich wskazanych tekstach i odzwierciedlającą istotę mitu Fedry jest ciało i seksualność. Ta hipoteza zostanie przeanalizowana w kolejnych sekcjach.

\section{Przygody ciała ${ }^{12}-$ diachroniczne resumé}

Jak wskazuje Erika Fischer-Lichte, współcześnie definiowane pojęcie „ucieleśnienia” podkreśla, ,że cielesne bycie człowieka w świecie stanowi pierwszy warunek możliwości pojawienia się ciała jako między innymi przedmiotu, tema-

10 Jako ,inwariant” rozważamy tutaj tę część mitu, która musi pozostać niezmienna, aby mit zachował chociaż zarys swej tożsamości.

${ }^{11}$ Badania porównawcze serii tematycznych (thématologie) nie należy sytuować w schemacie ewidencyjnego przeglądu wszystkich dzieł sygnowanych imieniem mitu. Janina Abramowska wskazuje na metodę „zmiennych przybliżeń”, badającą określone wycinki serii z pamięcią całości: „Wystarcza tu egzemplifikacja wybiórcza uwzględniająca punkty węzłowe i zestereotypizowaną postać tematu, do której odtworzenia nie potrzeba kompletu tekstów" (1992: 60-61).

12 Określenie ,przygody ciała” zostało zapożyczone z tekstu Zygmunta Baumana (1995). 
tu, źródła symboli, materiału do budowy znaków, produktu kulturowych zapisów" (2008: 143). Co więcej, rozważając istnienie człowieka w kontekście społecznym, Bauman zaznacza, że tkanka człowieczeństwa utkana $\mathrm{z}$ „myśli i emocji” została w świecie ponowoczesnym uzupełniona przez ciało ${ }^{13}$. Ponowoczesne ciało ${ }^{14}$ wpisuje się w egzystencję „zbieracza wrażeń” i jako „organ konsumpcji” i „,narzędzie przyjemności” dąży do zachowania sprawności rozumianej jako zdolność do odczuwania ekstatycznego ,podniecenia na widok podniet i radość z ich konsumpcji” (Bauman 1995: 90-91).

W tym kontekście mit Fedry wydaje się projektem konstytutywnym. Zainicjowany w kulturze starożytnej przywiązanej do idei sophrosyne (opanowania), odnowiony i kultywowany w epoce renesansu, a następnie ustanawiający, jako exemplum negatywne, bazę dla rozwoju nowożytnej wizji życia, mit ten w kulturze ponowoczesnej może być postrzegany jako mit fundujący ideę „zbieracza wrażeń”. W epoce starożytnej, oddanej umysłowej harmonii i zasadom wstrzemięźliwości, był on źródłem niepokojów i niepożądanych napięć. Każdorazowo jego manifestacja w przestrzeni sztuki postrzegana była jako exemplum negatywne, jako słowna i/lub wizualna przestroga przed tożsamością definiowaną poprzez ciało pożądające ekstatycznych doświadczeń. Senecjański wykład dotyczący emocji ${ }^{15}$, wpisujący się w stoicką teorię apatheia (braku cierpienia i wszelkich uczuć), ustanowił biegun inicjujący dla mitu Fedry. Totalność tej postawy ewokowała strategię życia w „zamkniętej twierdzy", kiedy rozum selekcjonuje impulsy zewnętrzne prospektywnie oceniane jako pathe (cierpienie) lub apathe (brak cierpienia). Taka postawa jednakże wymagała wycofania się z terytorium konsumpcjonizmu kreującego podniety, czyli z przestrzeni kultury. Renesansowa idea harmonii złagodziła stoicki profil egzystencji ,apatycznej”, przywołując Arystotelesowską formułę jedności psychofizycznej.

Należy jednak zauważyć, że owa psychofizyczna jedność nigdy nie sugerowała symetrycznej harmonii, w której umysł i ciało równoważnie definiowałyby człowieczeństwo. Z powodu „zwierzęcości” instynktów i żądz człowieka, ich istnienie, zaakceptowane jako naturalna konieczność, zostało poddane kontroli rozumu. W konsekwencji, Arystotelesowska jedność została przeformułowana w idę ciała bezwarunkowo zależnego od kontroli rozumu. Podobnie dyscyplinujące po-

13 „Ciało, podobnie jak myśli i uczucia, jest wytworem społecznym [...], sens 'bycia wytworem' ma swą historię w przypadku ciała podobnie, jak ma ją w przypadku myśli i uczuć [...].” (Bauman 1995: 70).

${ }^{14}$ Kulturotwórcze istnienie ludzkiego ciała było rozważane zależnie od kontekstu czasoprzestrzennego. Cywilizacja Zachodu w nowoczesności podkreślała istnienie ciała robotnika i żołnierza, które było produktem poddanym dyscyplinie tężyzny fizycznej tak dalece, jak było w stanie przynosić wymierne efekty dla przemysłu lub armii. Obie te panoptyczne przestrzenie egzystencji człowieka nowoczesnego stały się miernikami wartości jednostki trenowanej do życia w narzuconym rytmie taśmy produkcyjnej. $C f$. Bauman 1995: 77.

${ }^{15} \mathrm{Cf}$. Seneca, De ira (O gniewie). 
dejście do ciała i seksualności zostało rozwinięte przez etykę chrześcijańską. Seksualność rozumiana jako zwierzęce instynkty ${ }^{16}$ została poddana kontroli zgodnie z zasadami Judaizmu zaadoptowanego przez wczesne wspólnoty chrześcijańskie. W swojej radykalnej formie, chrześcijaństwo postulowało totalne odrzucenie tej sfery ludzkiego życia, odnajdując w niej znaki śmierci przenoszone na kobietę jako pułapkę żądzy (Brown 1988). Ponura wizja enkratyków, sekty chrześcijańskiej w specyficzny sposób transformującej Arystotelesowską ideę enkrateia ${ }^{17}$, proponowała definitywną eliminację seksualności z życia człowieka, w zamian deklarując jedność z duchem świętym ${ }^{18}$. Postulat szeroko rekomendowany w Kościele syryjskim nie został zaaprobowany przez Kościół rzymski, który z kolei wkomponował seksualność w swoją teorię społecznej użyteczności. Społeczna, czyli reprodukcyjna, rola seksu nadal pozostaje standardem w świecie chrześcijańskim, standardem szczególnie dotkliwym dla kobiet traktowanych jako obiekty poddane męskiemu libido.

Tak zdefiniowany standard stał się podstawą dla nowej wizji jednostki ludzkiej postrzeganej w roli „dostarczyciela dóbr”, którego istnienie było wartościowe jedynie w kontekście zdrowego ciała wydatkującego swoją energię w systemie produkcji (praca) lub obrony (walka) ${ }^{19}$. Wszelkie odchylenia od tak sformułowanych miar wydatkowania energii ciała było postrzegane jako złamanie standardu i manifestacja arogancji. Łatwo tu rozpoznać paralelę systemów kontroli ciała i umysłu, które charakteryzowały antyczne strategie społeczne jak i modernistyczny projekt postępu.

\section{Przygody ciała - synchroniczna (intertekstualna) tożsamość mitu Fedry}

Zasadniczą cechą dzieła literackiego, zarówno starożytnego jak i współczesnego, jest fakt, że dzieło stworzone wedle zasady mimesi ${ }^{20}$ jest zwielokrotnioną kontynuacją - mniej lub bardziej odległą - wcześniejszych tekstów poddanych imitacji i emulacji ${ }^{21}$. Tak opracowane dzieło zawiera zmodyfikowane znaczenia będące odmienną analizą tego samego pierwotnego szkicu (Guardini 1987: 7). Świadomość tradycji zatem konstytuuje rozwój literatury i wskazuje, że przeszłość jest zawsze dziedziczona przez nowe dzieła. Ciągłość tradycji literackiej

${ }^{16}$ Cf. Brown 1988.

17 Aristoteles, Ethica Nicomachea.

${ }^{18}$ Cf. Brown 1988: 110-113.

${ }^{19} C f$. Foucault 2000: 15: „(...) seks dlatego ujarzmiany jest z tak wielką surowością, że nie daje się pogodzić z powszechnym i wydajnym zatrudnieniem: czyż w epoce, w której siła robocza podlega systematycznej eksploatacji, można pozwolić, by zabawiała się innymi przyjemnościami niż te, które, ograniczone do minimum, umożliwiają jej reprodukcję?"

${ }^{20}$ Cf. Aristoteles, Poetyka 1447 a.

${ }^{21} C f$. Conte 1974: 5-14. 
i dyskusja z aktualnymi ideami i opiniami podejmowana przez autorów inicjuje powstawanie różnorodnych wariantów mitów. Taka sytuacja warunkowana jest głównie przez relację pomiędzy wersją mitu a czasem jej powstania, zważywszy na fakt, że mit odzwierciedla aktualne historyczne, społeczno-polityczne i religijne zjawiska. Wszelkie zmiany zachodzące w tych przestrzeniach ludzkiej aktywności jednocześnie determinują mityczną narrację $\mathrm{w}$ dziełach literackich $^{22}$. Tę współzależność w sposób szczególny odzwierciedla historia mitu Fedry ${ }^{23}$, który poprzez swoje różnorodne warianty stał się mitem syntetycznym, który odzwierciedla nie tylko historię, ale przede wszystkim sposób myślenia charakterystyczny dla ludzi w poszczególnych epokach, zgodnie z założeniem, że każde dzieło literackie odzwierciedla, do pewnego stopnia, społeczeństwo ${ }^{24}$.

A zatem parafrazując Brodskiego, można powiedzieć, że im głębiej tekst zanurza się w micie, tym bogatszy jest jego sens. Istotnie, czytelnik współczesny tym pełniej doświadcza owego bogactwa, im bardziej jest świadom nie tylko wieloaspektowości i wieloznaczności mitu, jego paradoksów i niekonsekwencji, lecz przede wszystkim tego, że ów mit w formie absolutnie oryginalnej nie istnieje, stanowi bowiem sumę swoich różnych wersji, mutacji i kolejnych „aktualizacji” (Sosień 2003: 16-17).

Poprzez zmiany w micie, zachodzące w różnych okresach czasu, możemy zaobserwować i zrozumieć zmienne historycznie realia, ale również dynamiczną naturę literatury. Analiza różnych wersji mitu pozwala uchwycić różne konteksty i kody kulturowe, w które uwikłany jest mit. Co więcej, możemy zauważyć przyczyny, dla których mit przestał być związany z religią i stał się atrakcyjnym motywem aktualnych dyskusji, krytyki lub nawet parodii. Ten proces jasno pokazuje, jak mit jest przekształcany w momencie przechodzenia ze sfery religijnej do estetycznej, stając się motywem literatury pięknej25.

${ }^{22} C f$. Guardini 1987: 8 (thum. M.B.): „Ta analiza pozwala nam zobaczyć jeszcze inną cechę greckiej literatury: fakt, że jest blisko związana, z jednej strony, z religią i mitem, z drugiej, z życiem politycznym, i wszelkie zmiany zachodzące $\mathrm{w}$ jednej z tych przestrzeni warunkują zmiany w pozostałych."

${ }^{23}$ Jak wskazuje Jacek Wachowski, mit Fedry był obiektem artystycznych i naukowych analiz i reinterpretacji począwszy od Racine'a i jego tragedii poprzez chrześcijańsko-metafizyczne wizje Francisa Mauriaca i Paula Valéry'ego, poetyckie rozważania Henri'ego Bremonda, strukturalistyczne badania Rolanda Barthes'a, po semiotyczne dywagacje Danielle i Davida Kaisergruberów i Jacques'a Lemperta i inscenizacyjne eksperymenty Gastona Baty'ego i Jean Louis Barraulta. Cf. Wachowski 1993: 6.

${ }^{24}$ Cf. Guardini 1987: 7.

${ }^{25} C f$. di Benedetto 1971. W odniesieniu do zmian w micie Maria Lia Guardini zauważa: „Jest zatem możliwe, poprzez lekturę wersji tego mitu, zrozumienie zmian historycznych, dywersyfikację funkcji literackiej i intelektualnej działalności w różnych kontekstach, oraz ujrzenie, że mit, jako obiekt wiary, stał się motywem dyskusji i desakralizacji, krytycyzmu i ironii, czysto estetyczną inspiracją dla literatury pięknej.” (1987: 8; tłum. M.B.). Warto również wspomnieć bardzo trafną uwagę Barbary Sosień: „W kulturach, gdzie mit przestał już pełnić rolę religijną, ten zbiorowy i/lub uniwersalny substrat przestaje funkcjonować jako bezpośrednia refleksja Sacrum, staje się nieprzydatny do wyjaśniania świata niepojętego.” (Sosień 2003: 15). 
Przywiązanie Fedry do normy formułowanej przez umowę społeczną konstytuuje zasadniczą ideę tragiczną mitu ${ }^{26}$. Eurypidejska wersja wydaje się być zatem pierwszą manifestacją niepokoju spowodowanego zniewoleniem jednostki przez wdrukowane normy kulturowe ${ }^{27}$. Zniewalająca siła narzucanych norm może być potwierdzona nie tylko przez najbardziej znaną wersję mitu przekazaną przez Eurypidesa w Hipolicie uwieńczonym, ale również przez jego poprzednią wersję, również autorstwa Eurypidesa, zaprezentowaną w zaginionej sztuce, Hipolicie zasłaniajacym oblicze. Ta pierwsza wersja została definitywnie odrzucona przez widownię, ponieważ przedstawiała zachowania stojące $\mathrm{w}$ jawnej opozycji do aktualnie obowiązujących zasad współżycia społecznego - pokazywała postać Fedry, która bezwstydnie ofiarowuje siebie Hipolitowi, łamiąc normę małżeństwa (przez cudzołóstwo) i rodzicielstwa (przez kazirodztwo). Dopiero kolejna, poprawiona wersja została oceniona i zaakceptowana jako politycznie poprawna, ale w sztuce tej Fedra przestała być odważnie „bezwstydna”, stając się wyłącznie „cierpiącą” z powodu wsty$\mathrm{du}^{28}$. Idea intelektualizmu ocen i wyborów ${ }^{29}$, która dominowała w klasycznym sposobie myślenia, minimalizowała lub zupełnie wyrzucała całą sferę ludzkiej emocjonalności i cielesności poza rozważania nad ludzkim ethos. Działanie inspirowane i kontrolowane przez rozum ${ }^{30}$ nie mogło, zgodnie $z$ intelektualistycznymi zasadami, prowadzić do złych rezultatów ${ }^{31}$. Emocjonalny zwrot Fedry stał się zatem głosem sprzeciwu wobec normy społecznej i w tym ujęciu został poddany pejoratywnej ekfrazie pociągającej za sobą gest samobójczy ${ }^{32}$. Czyn Fedry był wołaniem o jej własną podmiotowość, próbą wyrwania się z okowów kulturowej manipulacji ${ }^{33}$, która prowadzi do katastrofy. Używając

${ }^{26}$ Cf. Eur. Hipp. w. 392-399, 420-421, 715-721. Wszystkie cytaty oraz wersyfikację tragedii Eurypidesa podajemy na podstawie wydania: Eurypides 1967. Wydanie oryginału: Euripides 1914, ed. Murray.

${ }^{27}$ Cf. Eur. Hipp. w. 243-246, 364-365.

${ }^{28}$ Cf Hammer 1921: 5.

${ }^{29}$ Cf. Galewicz 2001: 29.

${ }^{30}$ Cf. Eur. Hipp. w. 1105-1106.

${ }^{31} C f$. Eur. Hipp. w. 377-383. Intelektualizm etyczny był idealistyczną propozycją Platona (Platon, Państwo, Księga IV). W jego opinii, racjonalna część duszy, logistikon, musi być ściśle powiązana z częścią duchową, thymoeides by móc nią zarządzać: „,- Nieprawdaż? Intelektowi władać wypada, bo jest mądry i powinien myśleć z góry o całej duszy, a temperament powinien mu podlegać i być z nim w przymierzu? - Tak jest.”(441 e). Te dwie części duszy natomiast powinny wspólnie nadzorować trzecią cześć, pożądliwą, „której jest najwięcej w duszy każdego, a taka już jej natura, że nie nasycą jej żadne skarby. Tamte dwa pierwiastki będą na nią uważały, żeby się nie syciła rozkoszami, które się nazywają cielesne, bo jak się przez to rozrośnie i wzmoże na siłach, to przestanie robić swoje, a zacznie brać za łeb i będzie próbowała rządzić tym, nad czym jej żadna władza nie przypada z natury, i całe życie zbiorowe do góry nogami wywróci." (442 a-b) Polski przekład na podstawie wydania: Platon 2003.

${ }^{32}$ Cf. Eur. Hipp. w. 139-140, 249, 277, 400-401, 599-600, 677-678, 723, 776-779.

${ }^{33}$ Cf. Eur. Hipp. w. 763-775. 
obrazu illicitus amor w opisie tej postaci, poeta mógł przedstawić sytuację rozdarcia pomiędzy obowiązkiem i próbą akceptacji własnej indywidualności, która manifestuje się poprzez pożądanie przeciwstawne akceptowalnym normom. Ambiwalentny węzeł uwikłania powstrzymuje Fedrę przed przekroczeniem normy ${ }^{34}$. Liminalny charakter sytuacji tej postaci powodowany jest strachem przed utratą tożsamości konstruowanej na bazie normy społecznej, ale również obawą przed nieznanym projektem tożsamości narzucanym, jak się wydaje Fedrze, z zewnątrz, pod imieniem boga, a będącym w istocie wewnętrznie skrywanym i thumionym konceptem indywidualizmu ${ }^{35}$. Projekt poszukiwania utraconej tożsamości wydaje się konstytuować inwariantowy aspekt mitu Fedry. Uchwycony w liminalnej fazie zawieszenia ujawnia całe spektrum socjo-kulturowych asocjacji ${ }^{36}$. Ambiwalentny węzeł zawiązany pomiędzy „chcieć” a „móc” demaskuje moment wykorzenienia z normy społecznej powodujący izolację i poczucie braku bezpieczeństwa ${ }^{37}$.

Klasycystyczne Rasynowskie dylematy Hipolita ${ }^{38}$, kolejnej postaci mitu Fedry, która jest $\mathrm{w}$ równej mierze uwikłana w labiryntowe poszukiwania tożsamości, wyrażają totalną i przemocową naturę bycia wewnętrznie zagubionym. Przemoc ukryta w liminalnych postawach Fedry i Hipolita wynika z ich poczucia konieczności odnalezienia „,siebie w sobie”, z potrzeby samopoznania i samookreślenia, tego rodzaju wewnętrznego anagnorismos, które można pogodzić z idealnym obrazem własnego ego. Przemoc i dotkliwość doświadczenia, w którym współuczestniczą Fedra i Hipolit, wynika z gwałtowności i radykalności zmiany, którą obserwują w sobie. Labiryntowa struktura poszukiwań tożsamości jest związana z geometrycznym układem ostrych cięć i załamań, z koniecznością cofania się i z paniką powodowaną przez brak możliwości odwrotu. Niemożność przekroczenia, które złagodziłoby cierpienie powodowane przez zmianę, jest inwariantowym doświadczeniem ukrytym w micie Fedry. Jest to zatem najwcześniejsza artystyczna egzemplifikacja niepokojów, które stały się dominantą rozważań nad tożsamością człowieka ponowoczesnego.

Jak wskazuje Barbara Skarga, kultura ponowoczesna hołubi zmianę i taka sytuacja tworzy obraz rzeczywistości kształtowany fraktalną geometrią chaosu,

${ }^{34}$ Cf. Eur. Hipp. w. 331, 1300-1312.

${ }^{35}$ Cf. Eur. Hipp. w. 141-142, 241, 359-360, 443-450, 1268-1281, 347-352, 725-727. Bogowie pojawiają się tutaj nie jako postacie z greckiej mitologii tylko jako personifikacje wewnętrznej energii ludzkiej duszy. Ich pojawianie się w sztukach Eurypidesa powinno być zawsze postrzegane jako konwencjonalny symbol funkcjonujący w micie, który posiada alegoryczne znaczenie, będąc figuratywnym i czytelnym narzędziem ekfrazy ludzkiej duszy.

${ }^{36}$ Cf. Eur. Hipp. w. 420-421.

${ }^{37} C f$. Merleau-Ponty 2001: 183: „Odkrywamy tym samym, że przekazy zmysłowe i wspomnienia ujmujemy wyraźnie i poznajemy tylko pod warunkiem, że utożsamiamy się z tą strefą naszego ciała lub życia, z której one pochodzą. To utożsamianie lub odmowa utożsamienia umieszczają podmiot w określonej sytuacji i wyznaczają pole psychiczne, którym on bezpośrednio dysponuje (...).”

${ }^{38}$ Racine, Phèdre, w. 548: "Maintenant je me cherche et ne me trouve plus" (Racine 2000) („Szukam siebie i znaleźć nie mogę.”; Racine 2002). 
w którym dominują ,progi, załamania, katastrofy, bifurkacje, rozproszony pył wydarzeń, działań myśli, pragnień zderzających się z sobą" (1999: 15). Zadziwiająco ponowoczesna natura mitu Fedry, obecna już w jej źródłowej greckiej wersji, jest potwierdzana we współczesnych rozważaniach nad tożsamością. Peter Sloterdijk, cytowany przez Skargę, zauważa:

Dla podmiotu tułającego się w swym byciu na współczesną manierę nie ma powrotu w identyczność. To, co nam się wydawało naszą własnością i było na samym początku, zostało stracone, staje się bowiem czymś innym, gdy tylko obejrzymy się za siebie (Skarga 1999: 15).

Co więcej, labiryntowa natura poszukiwań tożsamości jest w micie połączona z możliwością odnalezienia „potwora”, który jest znakiem tożsamości tłumionej i nie akceptowanej. Ten „potwór” w micie Fedry jest utożsamiany z ciałem i emocjami związanymi z seksualnościąa ${ }^{39}$. Potworność tak rozpoznanej projekcji tożsamości jest definiowana z perspektywy etycznych norm sophrosyne i apatheia. Senecjański koncept zamknięcia $\mathrm{w}$ twierdzy rozumu ${ }^{40}$ jest zatem diametralnie różny od idei totalnego otwarcia na zgiełk i przemoc świata zewnętrznego. Fedra rozpoznaje w sobie pragnienie zaakceptowania oferty proponowanej przez świat zewnętrzny, otwiera się na zmysłowe doświadczenie w pełnej świadomości przekraczania normy społecznej. Jest ona jednostką wykonującą inicjujący krok ku ponowoczesnemu projektowi strategii życiowej ukierunkowanej na doświadczenia ekstatyczne ${ }^{41}$. Współcześnie definiowany „zbieracz wrażeń” byłby zatem kolejną fazą zmiany tożsamości zachodzącą w trybie rewolucyjnym. Ponowoczesne ciało "musi się otworzyć szeroko i gościnnie na podniety zewnętrzne (...)" (Bauman 1995: 98), zaspokajając pragnienia doświadczeń ekstatycznych, ale jednocześnie wystawiając siebie na niebezpieczeństwo ataku zmasowanego i niekontrolowanego. Otwartość, którą Martha Nussbaum w odniesieniu do tragedii Seneki określa jako wystawienie się na okrutny gwałt i równie brutalną aborcję (2009: 457), prowadzi jednostkę ponowoczesną do nieustannej pogoni za napięciami i ich intensyfikacją ad extremum. Z drugiej strony, ewokuje ona konieczność obrony przed wypaleniem, aby nie zrujnować szansy na kolejne podniety i nowe ekstazy (Bauman 1995: 100). Schizofreniczne napięcie pomiędzy koniecznością posiadania zdrowego ciała rozumianego jako umiejętność absorbowania wrażeń, a strachem przed

${ }^{39}$ W greckiej mitologii Fedra była córką Pazyfae, królowej Krety, która, z woli bogów, zakochała się w byku. Dzieckiem zrodzonym z tej relacji był Minotaur, pół-człowiek pół-byk, ukryty przed światem w labiryncie.

${ }^{40}$ Sen. $P h$. w. $130-135$. Wszystkie cytaty z tragedii Seneki podajemy na podstawie wydania: Seneca, ed. Coffey\&Mayer 1990. Polskie thumaczenie: Seneka 1959.

${ }^{41} C f$. Merleau-Ponty 2001: 177: „Musi istnieć Eros i Libido ożywiające oryginalną odmianę świata, nadające seksualną wartość lub znaczenie zewnętrznym bodźcom i w każdym osobniku zakreślające użytek, jaki zrobi on ze swojego przedmiotowo traktowanego ciała”. 
ich nadmiarem i nieadekwatnością czyni życie „zbieracza wrażeń” niestabilnym i rozchwianym. Ponowoczesne wersje mitu Fedry Enquista i Tasnádiego przenoszą go w kolejne fazy poszukiwania tożsamości, umiejscawiając na ścieżkach i w zaułkach labiryntu znaczonych kwestiami genderowymi dotyczącymi kobiecej seksualności oraz wydajności ciała oscylującego pomiędzy pragnieniem przyjemności a paniką powodowaną ich spełnieniem, pomiędzy „książką kucharską" a „przewodnikiem odchudzania”, aby użyć trafnej metafory Baumana (1995: 98-99). Mit Fedry w jego ponowoczesnej reinkarnacji jest zatem tekstem zrekontekstualizowanym, jednakże wiernym swojemu estetycznemu i etycznemu inwariantowi.

Ponowoczesne wersje mitu Fedry, cytowane w spektaklu Kleczewskiej, wiążą się ze współczesnymi rozważaniami nad tożsamością w ich aspekcie genderowym. Jeżeli przełożymy diagnozy Baumana sugerujące dotkliwe uczucie „osobistej nieadekwatności”, wynikające z porażki w walce o samookreślenie, na sytuację postaci Fedry we współczesnych sztukach, zaobserwujemy daremne próby zaadoptowania własnej egzystencji do zasad Wielkiej Gry (Enquist) ${ }^{42}$ lub do ideologii psychoanalitycznego i fizycznego oczyszczenia (Tasnádi) ${ }^{43}$. Dramaturgia sytuacji Fedry jest rozgrywana w momencie uświadomienia sobie nieadekwatności jej własnej egzystencji w odniesieniu do odczuwanych pragnień. Oczywiście, ta adekwatność jest zmienną, która zależy od błądzenia poprzez kolejne korytarze labiryntu tożsamości. Życie przy boku Tezeusza, prowadzone zgodnie z zasadami Wielkiej Gry, wyczerpuje swoją pociągającą siłę pozornego bezpieczeństwa gwarantowanego przez nadzorujący i administrujący panoptikon męskiego Logosu. Skupiając wzrok na swoim własnym wnętrzu w sposób przynależny jednostce ponowoczesnej, Fedra zaczyna rozpoznawać swoje życie jako porażkę ${ }^{44}$. Tylko nowy bodziec, nowe „wydanie” Tezeusza, może być ucieczką. Jednak w tym pragnieniu jest głębsze, niż tylko seksualne podniecenie, żądanie własnej podmiotowości. Jest to życzenie „przybrania kształtu” definiowanego w całości przez kobiecość. Tożsamościowy postulat kobiety, kluczowy w sztuce Enquista, staje się próbą samookreślenia kobiecej seksualności, próbą przygody ciała zredukowanego przez wcześniejszą kulturę do funkcji reprodukcyjnej. Ponowoczesny projekt ciała poszukującego zmysłowej ekstazy jest kolejnym etapem dążenia ku kobiecej autoidentyfikacji bez mediacji modelu męskiego Logosu. Równościowy charakter tego doświadczenia jest potwierdzany przez

${ }^{42}$ Cf. Enquist, Till Fedra, s. 136: "stora spelet" [Wielka Gra]. Wszystkie cytaty ze sztuki Enquista podajemy na podstawie wydania: Enquist 2014. Polskie wydanie: Enquist 1997.

${ }^{43}$ Cf. Tasnádi, Phaidra. Végsö Aktus, s. 7: "lelki wellness" [duchowy dobrostan]. Wszystkie cytaty ze sztuki Tasnádiego podajemy na podstawie wersji tekstu Phaidra. Végső Aktus opublikowanego na stronie: http://www.dramairo.hu/hu/konyvtar.html [14.12.2014]. Polskie wydanie: Tasnádi 2000.

${ }^{44}$ Cf. Enquist, Till Fedra, s. 104. 
oba teksty, Enquista ${ }^{45}$ i Tasnádiego ${ }^{46}$, w których rozgrywany jest Rasynowski motyw zagubionej męskiej tożsamości Hipolita. Kultura ponowoczesna bowiem próbuje zjednoczyć doświadczenia ciał mężczyzny i kobiety w obliczu nadmiaru bodźców zewnętrznych i pragnień modulowanych wewnętrznie do spełnienia. Dlatego mit poszerza pole swojej identyfikacji o rozważania nad gyne- i andro-pauzą postrzeganą jako liminalne doświadczenie zmiany (pausa $)^{47}$ genderowej autoidentyfikacji.

Zatem żądanie zerwania introjekcji normy formułowanej przez męski Lo$\operatorname{gos}^{48}$ konstytuuje inwariant mitu Fedry. Zasadnicza różnica, która ma miejsce w ponowoczesnych rekontekstualizacjach, nie dotyczy istoty problemu, ale jego intensyfikacji. Antyczny projekt Eurypidesa, kreujący mityczną postać uwikłaną w doświadczenie pierwszych prób wyjścia poza normę definiowaną zewnętrznie ku normie określanej przez podmiot, zostaje przekształcony w ponowoczesny projekt konieczności odrzucenia normy zewnętrznej i przymusu identyfikacji skupionej wewnętrznie ${ }^{49}$. Paradoksalnie jednak, przymus dotyczący wolności pragnień i działań zmusza do nieustannego poszukiwania wsparcia ze strony normy. Uwolnienie ciała od nadzoru Logosu powinno być postrzegane jako pozytywne posunięcie ku prawdziwszemu rozpoznaniu człowieczeństwa. Mimo to wolne ciało zmaga się z ogromem bodźców i impulsów świata obiektów i z przymusem ich akceptacji i absorpcji. Ponowoczesna Fedra osiąga kolejny punkt graniczny, w którym wolność, osiągnięta przez odrzucenie norm Logosu, staje się zniewoleniem przez bodźce wywołujące namiętności i obsesje.

\begin{abstract}
Wścibski nadzorca, surowy majster i wszechwiedzący nauczyciel usunęli się z pola widzenia, a wraz z nimi odeszła ich moc przymuszania, ale też i ich dar rozgrzeszania z odpowiedzialności. Można teraz liczyć tylko na nadzór własny, samokontrolę i taką wiedzę, jaką posiąść może samouk. Człowiek jest sam sobie dozorcą i nauczycielem; parafrazując Maurice’a Blanchota powiedzieć można, że każdy jest dziś wolny wewnątrz własnego więzienia, jakie sam dla siebie, własnymi rękoma i z własnej woli, buduje (Bauman 1995: 85).
\end{abstract}

Ta idea dotyczy sytuacji Fedry, której wolność wyboru jest w równym stopniu paraliżowana przez normy zewnętrzne jak i przez subiektywne uczucie nie-

${ }^{45} C f$. mowę Hipolita w sztuce Enquista, Till Fedra, s. 114-115.

${ }^{46} C f$. Nyolcadik Jelenet [Scenę Ósmą] w sztuce Tasnádiego, Phaidra. Végsö Aktus, s. 32.

${ }^{47}$ Greek-English Lexicon 1883, s. 1164-1165: s.v. $\pi \alpha v \omega \omega$ - doprowadzić do końca, zatrzymać, cofnąć (tłum. M.B.).

${ }^{48}$ Cf. Skarga 1999: 14, gdzie filozofka cytuje Jean-Marie Benoista: „[logos] dokonuje aneksji przy pomocy zasady identyczności tego, co odbiega od drogi, tocząc się po stromych zboczach tego, co różne, odmienne, wyalienowane. Wszystko chce wchłonąć, triumfalnie podporządkować statecznej i obojętnej pewności, którą rodzi ta uspokajająca identyczność bytu z samym sobą pojęta jako obecność i bliskość". (Benoist 1975: 16).

${ }^{49} C f$. Bauman 2000: 33: „Ponowoczesność żyje w atmosferze nieustannego nacisku na rozmontowywanie wszelkich ograniczeń narzucanych zbiorowo losom jednostek - presji deregulacyjnych i prywatyzacyjnych". 
adekwatności i uciążliwości nowo rozpoznanych pragnieńn ${ }^{50}$. Ponowoczesne uczucie zniewolenia we własnym projekcie identyfikacji z pragnieniem jest istotowym elementem kształtującym inscenizację Kleczewskiej.

\section{Przygody ciała - ucieleśnienie mitu na scenie}

W kontekście ponowoczesnego projektu ciała w spektaklu Kleczewskiej, fraza z tekstu Enquista wydaje się być najbardziej znacząca: „Jag är ju inget djur” („Nie jestem zwierzęciem” (s. 127). Ten krzyk jest rozgrywany na scenie w momentach erotycznej ekstazy. Ekstatyczne przygody ciała i etyczne niepokoje z tym związane są pokazywane na scenie zgodnie z zasadami „mokrego teatru”, który działa głównie przez fizjologię ciała aktora (Pavis 2011: 310).

W inscenizacji Kleczewskiej Fedra (Danuta Stenka) pojawia się na początku jako kobieta $\mathrm{z}$ grymasem maski. Ubrana jest w elegancką suknię w neutralnym kolorze, ale jej rozłożysty kapelusz, okulary przeciwsłoneczne i długie czerwone rękawiczki ujawniają wolę ukrycia nieakceptowalnej części jej własnej osobowości definiowanej przez pragnienie. Ta krucha próba oszukania świata i siebie samej zostaje zdemistyfikowana przez rekwizyt - parę chartów. Jest to oczywiste odniesienie do Hipolita, którego mityczna tożsamość łączy się z toposem myśliwego. W tej scenie Fedra wyraża swoje pragnienie bezsłownie, ale jest to tylko gest zapowiadający jej wielką przemowę przejętą z tekstu Eurypidesa ${ }^{51}$. Pragnienie Fedry dotyczące jej uczestnictwa w polowaniach wraz z Hipolitem jest jej wyznaniem miłości i pożądania wyrażonym implicite w rozbudowanej ekfrazie wspólnego doświadczenia obecności. Ten specyficzny rodzaj synekdochy wykorzystany w sztuce Eurypidesa jest rozgrywany na scenie w celu wyrażenia pasji kobiecego pożądania bez wskazywania jego obiektu.

Wijąca się na stole i płacząca Fedra w kolejnych scenach przedstawienia staje się obrazem walki z samą sobą. Ujawnia również swoje seksualne pragnienia poprzez gesty masturbacji przerywane krzykiem z Enquista: „Nie jestem zwierzęciem!” (s. 127). Ten jednoznaczny i dosłowny obraz seksualnego pożądania jest cechą postmodernistycznego teatru stosującego estetykę szoku i odrazy. Hyperekspresyjność Fedry zawłaszcza scenę, która jest ascetyczną przestrzenią imitującą minimalistyczny wystrój domu. Stół, jako dominujący rekwizyt, jest miejscem spotkań i znakiem skupienia relacji pomiędzy postaciami scenicznymi. Ale na tym stole Fedra ujawnia swoje kazirodcze pragnienia seksualne i ten gest może być postrzegany jako znak zniszczenia rodziny.

${ }^{50} C f$. Nancy 2002: 52: „Mamy tu więc do czynienia z podwójną porażką: niemożnością mówienia o ciele, ale i niemożnością przemilczenia go. Double bind, psychoza. Jedyne wejście do ciała, jedyny dostęp do każdego z jego wejść jest wstąpieniem w szaleństwo."

${ }^{51}$ Eur. Hipp. w. 208-211, 215-221, 228-231. 
Sceniczna egzystencja Hipolita (Michał Czernecki) jest określana głównie przez pryzmat sztuki Sarah Kane, Miłość Fedry (2002), która jednak nie została wspomniana w tekstualnej bazie tego przedstawienia. Autodestrukcyjna natura gry aktorskiej postaci Hipolita, rozgrywana na scenie w znakach krwi, strzępów ciała i fizycznie wyczerpujących gestów, odnosi się do zasadniczego konceptu samozagubienia. Formowanie dorosłego mężczyzny i rytuały inicjacyjne związane z konstytuowaniem się dojrzałej tożsamości są najbardziej traumatycznymi rytuałami przejścia w rozwoju umysłowym i fizycznym. Jest to również jedyny moment refleksji nad wdrukowanymi przez kulturę normami ludzkiej egzystencji. Kleczewska reżyseruje tę kwestię poprzez obrazy zachowania Hipolita ocierające się o szaleństwo.

Spotkanie dwojga protagonistów w akcie wyznania miłości zostało znacząco skonstruowane przez reżyserkę. Zapośredniczone wyznanie stanowi kluczowy motyw w kanonicznej wersji Eurypidesa. Antyczna idea aidos (wstydu) została ukazana na scenie poprzez medium telefonu, kiedy Fedra nie musi znosić karzącego spojrzenia Hipolita. Jednakże, wyznanie Fedry jest słyszane przez Hipolita i jej telefoniczny monolog przeradza się w upokarzający dialog. W tej scenie Senecjański gest Fedry klęczącej przed Hipolitem ${ }^{52}$ jest powtórzony w jej błaganiu o miłość. Kleczewska rozwija tę całkiem czytelną scenę z rzymskiego dramatu, kiedy jej Fedra klęcząc, rozbiera Hipolita, dezintegrując jego fizyczną nienaruszalność.

Wyczerpująca gra aktorów odgrywających główne role zostaje zestawiona z milczącą obecnością postaci Tezeusza (Jan Englert). Leży on w łóżku szpitalnym, pozostając w śpiączce, która jest rekontekstualizacją jego mitycznej wyprawy do Hadesu przejętą ze sztuki Tasnádiego. Umiejscowienie łóżka z Tezeuszem po jednej stronie sceny i jego permanentna obecność podczas wszystkich wydarzeń scenicznych jest widocznym znakiem obecności determinującej bieg wydarzeń na scenie i stającej się rdzeniem sytuacji tragicznej. Jednocześnie, swoistość milczącej obecności ciała pozbawionego ducha, który jest „ciałem sensu” (Nancy 2002: 69), prowokuje w postaciach otaczających króla pragnienie okrutnej gry - zabawy z sensem tego zwiędłego, starczego ciała, którego bijące serce jest jedynym znacznikiem władzy.

Taniec z łóżkiem Tezeusza, rozgrywany przez Teramenesa (Paweł Tołwiński), Panope (piastunka Fedry; Kamilla Baar) i Minotaura (Przemysław Stippa), wizualizuje Wielką Grę opisaną w tekście Enquista i rozwiniętą w sztuce Tasnádiego w dyskusjach o eutanazji bezproduktywnych starców. Wszystkie główne postacie na scenie rozmawiają z ciałem Tezeusza, każda z nich sprowadza swoje działanie do tej milczącej figury władcy, która terroryzuje swoją obecnością całą rodzinę. Nikt nie jest wystarczająco odważny by wyłączyć aparaturę podtrzymującą życie, jakkolwiek wszyscy życzyliby sobie śmierci Tezeusza. Wszyscy po-

${ }^{52}$ Sen. $P h$. w. 636-659. 
trafią grać z tym ciałem pozbawionym ducha, potrafią prowadzić z nim cyniczne konwersacje na temat bezcelowości podtrzymywania go przy życiu, ale nikt z nich nie potrafi wykonać gestu królobójstwa.

Strategie gry aktorskiej w spektaklu Kleczewskiej potwierdzają, że przekonanie o medialnej naturze ciała aktora powinno być zrewidowane. Fenomenalne ciało aktora musi wpisywać się w konstytutywne znaczniki postaci. W odniesieniu do tego zagadnienia, Erika Fischer-Lichte przywołuje filozofię „mięsa” Maurice’a Merleau-Ponty’ego, określając ją jako „projekt połączenia ciała i duszy, zmysłowego i ponadzmysłowego $\mathrm{w}$ niedualistyczny i nietranscendentalny sposób" (Fischer-Lichte 2008: 134) ${ }^{53}$. Sztuka inscenizacji, która jest rozgrywana cieleśnie, wzmacnia dość oczywisty fakt, że ludzka physis jest „korelatem zarówno zwierzęcości, jak i człowieczeństwa" (Merleau-Ponty 1996: 181).

Relacje w obrębie obu tych dychotomii nie są symetryczne. To, co cielesne i zmysłowe, zostaje uprzywilejowane. Ciało zawsze łączy się ze światem poprzez „mięso”. Każde wejście człowieka w świat dokonuje się poprzez ciało i ma cielesną naturę. Ze względu na mięsność ciała nie można sprowadzić go do funkcji instrumentalnej i semiotycznej (Fischer-Lichte 2008: 134).

Dlatego Merleau-Ponty wyraźnie wskazuje, że seksualność jest sferą wewnętrznie związaną ,z całym poznającym i działającym bytem” (2001: 178) ${ }^{54}$. Ciało jest warunkiem możliwości ludzkiej egzystencji jako „ukryta forma bycia sobą” (2001: $186)^{55}$. Ciało człowieka, a więc również aktora, jest dokładnie tym, co oznacza, nie jest znakiem niosącym znaczenie, lecz jest przez to znaczenie zamieszkiwane. Jako „nowe formy dawnych pytań”, Patrice Pavis wskazuje właśnie odzyskanie na scenie praw ciała, które wcześniej pełniło służebną rolę znakową (2011: 289). Ciało, poprzez swoją wielostabilność i nieustanną transformację, jest szybsze niż słowo i często staje się najbardziej adekwatnym medium ekspresji. Tak rozumiana sceniczna ekspresja „pozwala zobaczyć i odczuć przemieszczenia, zderzenia, rewolty i konflikty zbuntowanych ciał" (2011: 290).

Jednakże inscenizacja bazująca na tekście literackim nieuchronnie mierzy się z konfrontacją pomiędzy dwoma dyskursami, referencjalnym i performatywnym, które są rozgrywane na scenie słowami i ciałami (Adamiecka-Sitek 2005: 113). Inscenizacja mitu Fedry wydaje się specyficznym zderzeniem semiozy i performatywności, zważywszy na fakt, że sam mit oscyluje wokół kwestii dotyczących erotyzmu, seksu i miłości oraz ich znaczeń w kulturze Logosu. Mit, który ujawnia logocentryczną narrację dotyczącą ciała i seksualności, odnajduje najbardziej (1996).

${ }^{53}$ E. Fischer-Lichte odwołuje się tutaj do dzieła Merleau-Ponty'ego Widzialne i niewidzialne

${ }^{54} C f$. też: Merleau-Ponty 2001: 187: „Ani ciała, ani egzystencji nie można uznać za oryginał ludzkiego bycia, ponieważ zakładają się one nawzajem, ponieważ ciało jest zastygłą lub uogólnioną egzystencją, a egzystencja nieustannym wcieleniem”.

${ }^{55}$ Merleau-Ponty cytuje tutaj Binswangera „eine verdeckte Form unseres Selbstseins". (Bonswanger 1935: 188). 
adekwatne medium dla swojej translacji w tekście dramatu. W inscenizacji Kleczewskiej istota mitu Fedry zostaje trafnie rozpoznana. Jego zasadniczy temat odnosi się bowiem do erotyzmu rozumianego jako energia ludzkiej wyobraźni skupiona na ciele i pożądaniu, wahająca się pomiędzy funkcjonalnym i teleologicznym seksem a miłością romantyczną, istniejąc jednocześnie jako autonomiczna sfera ludzkiej aktywności ${ }^{56}$. Subtelność i psychiczny status inscenizowanego fenomenu wymaga zbalansowania znaków re-prezentujących signifié mitu i fenomenalnej obecności ciał aktorów. Dlatego rozważana kwestia jest komunikowana kompleksowo przez słowo i gest.

Postaci sceniczne w spektaklu Kleczewskiej są ,produkowane” przez fizyczną cielesność ciał aktorskich. Pokazywanie (przez reżyserkę) i oglądanie (przez widownię) zindywidualizowanej cielesności ciał aktorów powoduje „percepcyjną wielostabilność" i wieloznaczność (Fischer-Lichte 2008: 142). Transformatywna natura ludzkiego ciała, pozostającego w ciągłej zmianie, pozwala aktorom tworzyć postacie wolne od stabilnej i ostatecznej formy. Kreując postać sceniczną, aktor ma możliwość wyprodukować na scenie ten szczególny rodzaj energii, który emanuje z jego fizycznej obecności. Rozważając koncept „obecności” Lehmanna, rozumianej jako cielesna forma procesu świadomości (Lehmann 1999), Fischer-Lichte powraca do teorii Merleau-Ponty'ego, która usuwa binarną dychotomię ciała i umysłu.

Kiedy aktor wytwarza własne ciało jako energetyczne i w ten sposób eksponuje własną obecność, wtedy objawia się jako wcielony umysł, to znaczy jako istota, w której ciało i umysł/ świadomość nie dadzą się żadną miarą od siebie oddzielić, gdyż oba te elementy stanowią od samego początku integralną całość (Fischer Lichte 2008: 160).

Fenomenalna energia ciał aktorskich w spektaklu Kleczewskiej staje się dodatkowym lub nawet najbardziej znaczącym kanałem energetycznym intensyfikującym semiotyczne procedury translacyjne. Sugerowane znaki teatralne przyjmują tutaj głównie walory estetyczne ${ }^{57}$, ponieważ nagie ciało aktora, kolory scenografii i kostiumów, muzyka i gesty tworzą obrazy będące częścią dramaturgii zatłoczonej sceny ${ }^{58}$. Z tego powodu odzyskanie walorów semantycznych poszczególnych znaków wymaga szybkiej i kompetentnej reakcji widza. Jakkolwiek, gra gęstością znaków prowadząca do nadmiaru powoduje w widzu przejście od początkowego szoku do finalnego zobojętnienia. Ponowoczesna tendencja do namnażania gęstości i ilości bodźców prowadzi do odcięcia percepcji od cielesno-zmysłowego kryterium i skupienia na powierzchownej rejestracji rzeczywistości scenicznej Lehmann 2004: 147-138). Spektakl Kleczewskiej gra z widzem, atakując go nadmiarem obrazów i muzyki, ograniczając dyskusję o ciele do perwersji.

\footnotetext{
${ }^{56}$ Cf. Bauman 1998.

7 Cf. Kowzan 1998.

${ }^{58} C f$. Ubersfeld 2002: 138.
} 
To emergentne wrażenie perwersyjnego zanurzenia w fizjologii ciał aktorów jest powodowane przez nasze kulturowe uwarunkowania percepcji. Zgodnie z nimi, nagość lub akt seksualny widoczny w sferze publicznej jest uznawany za perwersyjne przekroczenie. Zmuszanie widza do oglądania nagich ciał zanurzonych we krwi czy też poddanych aktom seksualnym jest bez wątpienia aktem przemocy, który podkopuje kulturowo i społecznie uwarunkowane granice wizualizacji części ciała związanych z fizjologią ${ }^{59}$. Wówczas, przekraczając emocje zawstydzenia czy wstrętu, podejmuje się próbę analizy tak zaprogramowanego ataku na schematy percepcyjne. Dlatego wydaje się, że ten rodzaj zabiegów scenicznych, związany z estetyką brutalizmu, ustanawia tymczasowe medium zastosowane do wywołania społecznej reakcji porównywalnej z tą, która miała miejsce wśród ateńskiej widowni ${ }^{60}$. Kwestia dotyczy podobnego gestu reżysera, który dąży do wywołania uczuć litości i trwogi, katartycznych stanów przepracowywania tłumionych emocji.

Ból, przemoc, śmierć i wywołane przez nie uczucia, przerażenie i współczucie (Frucht und Mitleid), od czasu antyku decydowały o tym, że ,tragiczny temat sprawiał odbiorcom przyjemność”. Dzisiaj starożytny eleos i phobos częściej oddaje się jako rozpacz i trwogę (Jammer und Schaudern). W Poetyce zakładał Arystoteles zaangażowany udział widzów w teatralnym widowisku; intensywne, cielesne przeżywanie określonych momentów scenicznej akcji. Estetyka współczesnych mediów odwołuje się nie tyle do obrazów śmiertelnego ciała, ile obrazów ciała torturowanego; do obrazów ciała, któremu zadaje się ból (Lehmann 2004: 181).

Równowaga pomiędzy trwogą i współczuciem w tej inscenizacji wydaje się być zachowana, jakkolwiek nie jest to oczywista sytuacja we współczesnym teatrze, ponieważ w ponowoczesnej inscenizacji nie ma miejsca na Arystotelesowską litość. Postacie sceniczne jednoznacznie ewokują głównie strach, tracąc swój tragizm rodzący się wówczas, gdy dobry człowiek zostaje uwikłany w zło. Postać Fedry w spektaklu Kleczewskiej prowokuje uczucia empatyczne tylko w widzu posiadającym odpowiednie kulturowe i społeczne kompetencje. Zdolność rozpoznania w gestach aktorki znaków przemocy, w które uwikłana jest Fedra, musi wynikać z wrażliwości i z kompleksowego społecznego zaplecza tak, by nie osiąść na mieliźnie powierzchownej percepcji skondensowanych i szokujących znaków. Autopojetyczna pętla feedbacku wzmacnia relacje między aktorami i widzami w równym stopniu na poziomie fenomenologicznego performansu hic et

${ }^{59} C f$. Lehmann 2004: 279: „W postdramatycznym teatrze ciało nie zostaje wystawione na widok publiczny ze względu na swoje sąsiedztwo z ideałem, lecz jako powód do sprawiającej cierpienie konfrontacji z niedoskonałością".

${ }^{60} C f$. Sarrazac 2007: 74, s.v. katartyczny (materiat): „(...) Również teatr współczesny (postmodernistyczny) stara się wzbudzić te dwa typy uczuć [litość i trwogę]. Nie posługuje się on jednak kanonicznymi formami, które prowadzić mogą do tradycyjnego katharsis, ale wykorzystują nowe strategie, charakterystyczne dla z gruntu niekanonicznego pisania dla teatru". 
nunc jak i w mentalnej przestrzeni analizy asocjacyjnej opartej na indywidualnych wspomnieniach i doświadczeniach widza oraz na intersubiektywnych kodach kulturowych (Fischer-Lichte 2008: 231). Przywoływanie intersubiektywnie obowiązujących kodów kulturowych wydaje się kluczowe dla odbioru spektaklu Kleczewskiej, zważywszy na fakt, iż bazuje on na micie mającym bogatą tradycję recepcyjną. Wysoce rozwinięta sfera indeksu mitu Fedry powoduje kreację asocjacyjną, w którą widz jest również zaangażowany, ponieważ mit dotyczy tabu sfery erotyzmu, seksu i miłości kulturowo przemilczanego i nadal poszukującego języka dla tego rodzaju współzależnej koegzystencji.

\section{Konkluzja}

Intertekstualna baza tego przedstawienia pozwoliła reżyserce na dyslokację rdzenia mitu i na redefinicję inwariantu, który osiągnął odmienne, czasami subwersywne, formy w zestawieniu tekstów starożytnych i ponowoczesnych. Podkreślając tak dynamiczną transtekstualną relację, Kleczewska sugeruje wstępne założenie dla swojej inscenizacji, kierując widza ku lekturze polisemicznej. Akcentując różnicę pomiędzy interpretacjami mitu $\mathrm{w}$ dramatach $\mathrm{z}$ różnych przestrzeni kulturowych, reżyserka wskazuje jednocześnie na różnicę pomiędzy systemami znakowymi medium tekstu i medium teatru. Literackość i teatralność mitu Fedry są tematyzowane w przestrzeni scenicznej, gdzie reżyser staje się mediatorem pomiędzy tekstem a jego inscenizacją, mediatorem, który wypełnia lukę istniejącą w równej mierze w tekście literackim, jak i teatralnym (Ubersfeld 2002: 20). Wzajemne uzupełnianie luk w obu systemach znakowych - językowych tekstu literackiego i audiowizualnych tekstu teatralnego - jest interpretacyjnym gestem twórcy scenicznego. Zatem inscenizacja Kleczewskiej może być postrzegana jako dekonstrukcyjna lektura mitu Fedry, która ma na celu ujawnić nieusuwalne napięcie pomiędzy konstytutywnym i performatywnym użyciem języka (Markowski 2006: 375).

W tej szczelinie między moim przyzwoleniem a jego/jej wypowiedzią, podobnie jak między tradycją a jej odczytaniem, między dwoma podpisami, otwiera się możliwość osobliwego jednostkowego zdarzenia, którego dekonstrukcja jest nieustanną afirmacją (Markowski 2006: 371).

Każdorazowa konkretyzacja tekstu na scenie jest zdarzeniem o charakterze inwencyjnym, ponieważ ustanawia kontrasygnatę reżysera warunkowaną przez zespół czynników: signifiant (dzieło literackie), signifié (obiekt estetyczny) i metatekst (kontekst społeczny) (Pavis 1989: 108). Uwarunkowanie metatekstualne określane w ramach zjawisk społeczno-kulturowych jest zmienną, która modyfikuje znaczenia produkowane w akcie lektury. Jakkolwiek, metatekst, który istnieje „nie tyle obok tekstu dramatycznego, ile - w pewnym sensie - wewnątrz niego, jako rezultat procesu konkretyzacji (od signifié przez kontekst społeczny do 
signifiant)" (Pavis 1989: 109), wydaje się być najistotniejszy. Tak zdefiniowany metatekst istnieje tylko w formie zrekonstruowanej przez odbiorcę, dlatego jest sumą rozdzielenia ,dodatkowego przydziału” (ration supplémentaire), który dąży do wypełnienia luki.

\begin{abstract}
Nie można określić centrum, znaku, który je uzupelnia [supplements], który zachodzi pod jego nieobecność, albowiem znak ten dołącza się, pojawia się dodatkowo, jako dodatek, przychodzi jako uzupełnienie [supplement]. (...) ale ten dodatek jest ruchomy, ponieważ pojawia się, by spełnić funkcję zastępczą, uzupełnić brak ze strony signifié (Derrida 1986: 9; podkreślenia $\mathrm{w}$ oryginale $)^{61}$.
\end{abstract}

Dla zrozumienia znaczenia mitu Fedry, należy przeanalizować jego początki jak również sukcesywnie rozwijaną kompleksowość warunkowaną absorbowanymi elementami kulturowymi i historycznymi. Złożoność oryginalnego rdzenia mitycznego wydaje się nieodzowna ${ }^{62}$, ponieważ sam mit w sposób znaczący pozostaje aktywny, nawet poza czasoprzestrzenią swoich narodzin. Ten proces delaminacji może być potwierdzany przez analizy różnych wariantów mitu Fedry, które odkrywają jego złożoną strukturę, ujawniając stopniowe modyfikacje intelektualnego znaczenia zależnego od danej czasoprzestrzeni. $\mathrm{Z}$ tego powodu mamy tutaj do czynienia z kompleksowym zjawiskiem transkodyfikacji, w którym opowieść nawet posiadająca tę samą strukturę jest przekazywana w różnych kodach, co znacząco zmienia jej znaczenia.

Efektem każdego aktu recepcji dzieła jest swego rodzaju synteza intertekstualna: świadomość funkcjonowania tekstu w przestrzeni intertekstualnej pozwala zrozumieć dzieło poprzez jego mnogi charakter. Taka synteza to nie uspokojony schemat, ale nieustające napięcie, które jest źródłem postrzegania sensów, podstawą rozumienia (Sosień 2003: 29).

\title{
Bibliografia
}

Abramowska, J. (1992). Serie tematyczne. W: J. Ziomek et al. (eds.). Między tekstami. Intertekstualność jako problem poetyki historycznej. Warszawa: PWN.

Adamiecka-Sitek, A. (2005). Teatr i tekst. Inscenizacja w teatrze postmodernistycznym. Kraków:

Księgarnia Akademicka.

Aristotle (1882). Ethica Nicomachea. Lipsiae: Teubner. Book VII.

Arystoteles (1983). Poetyka. Przeł. H. Podbielski. BN II nr 209. Wrocław: Ossolineum.

${ }^{61}$ Cf. Eco 1986: 23 (tłum. M.B.): „Natura znaku może zostać odnaleziona w 'ranie' lub w 'otwarciu' lub w 'rozchyleniu', które go ustanawiają i anulują w tej samej chwili. Ta idea, chociaż mocno rozwinięta przez myśl poststrukturalną, szczególnie Derridy, w istocie rozwinęła się znacznie wcześniej. W krótkim tekście De organo sive arte cogitandi, Leibniz, poszukując określonej liczby myśli, z których kombinacji wszystkie pozostałe mogą być wywiedzione (jak w przypadku liczb), lokuje zasadniczą matrycę kombinatoryjną w opozycji między Bogiem a nicością, obecnością a nieobecnością. Binarny system kalkulacji jest cudownie podobny do tej dialektyki”.

${ }^{62}$ Cf. Seppilli 1982: 382. 
Arystoteles (2007). Etyka Nikomachejska. Przeł. D. Gromska. Warszawa: PWN.

Bauman, Z. (1995). Ciało i przemoc w obliczu ponowoczesności. Toruń: UMK.

Bauman, Z. (1998). “On Postmodern Uses of Sex”. Theory, Culture \& Society 15.3-4 (1998). 19-33.

Bauman, Z. (2000). Ponowoczesność jako źródło cierpień. Warszawa: Sic!

Benoist, J. M. (1975). Tyrannie du logos. Paris: Minuit.

Blumenberg, H. (1985). Work on Myth. Trans. R. M. Wallace. Cambridge: MIT Press.

Blumenberg, H. (2009). Praca nad mitem. Przeł. K. Najdek, M. Herer, Z. Zwoliński. Warszawa: Oficyna Naukowa.

Bonswanger, L. (1935). Über Psychotherapie. Möglichkeit und Tatsächlichkeit psychotherapeutischer Wirkung. Vortrag. Wien: Springer.

Brown, P. (1988). The Body and Society: Men, Women and Sexual Renunciation in Early Christianity. New York: Columbia University Press.

Budzowska, M. (2017). Sceniczne metamorfozy mitu. Teatr polski XXI wieku w perspektywie kulturowej. Łódź: Wydawnictwo Uniwersytetu Łódzkiego. [w druku]

Budzowska, M., Czerwińska, J. (2015). Intersemiotic translation of the ancient myth in the production of Phaedra by Maja Kleczewska. In: The Power of Intellect. Umberto Eco - reception and reminiscences in Poland, A. Gałkowski (ed.). Łódź: University of Lodz Press. 323-348.

Conte, G. B. (1974). Memoria dei poeti e sistema letterario. Torino: Giulio Einaudi editore.

Derrida, J. (1986). „Struktura, znak i gra w dyskursie nauk humanistycznych”. Przeł. M. Adamczyk. Pamiętnik Literacki LXXVII, 1986, z. 2. 259-263.

di Benedetto, V. (1971). Euripide: teatro e società. Torino: Giulio Einaudi editore.

Durand, G. (1979). Figures mythiques et visages de l'oeuvre, Paris: Berg International.

Eco, U. (1981). "The Theory of Signs and the Role of the Reader", The Bulletin of the Midwest Modern Language Association, 14.1 (Spring 1981). 35-45.

Eco, U. (1986). Semiotics and the Philosophy of Language. Bloomington: Indiana University Press.

Enquist, P. O. (1997). Dla Fedry, Z życia glist, Godzina kota, Tulipak. Przeł. A. Krajewski-Bola. Izabelin: Świat Literacki.

Enquist, P. O. (2014). Dramatik. Tribadernas natt; Till Fedra; Från regnormarnas liv; I lodjurets timma, Stockholm: Norstedts.

Euripides. (1913). Euripidis Fabulae. Vol. 3. G. Murray (ed.). Oxford: Clarendon Press.

Eurypides (1967). Tragedie. T. I. Przeł. J. Łanowski. Warszawa: PWN.

Fischer-Lichte, E. (2008). Estetyka performatywności. Przeł. M. Borowski, M. Sugiera. Kraków: Księgarnia Akademicka.

Foucault, M. (2000). Historia seksualności. Przeł. B. Banasiak, T. Komendant, K. Matuszewski. Warszawa: Czytelnik.

Galewicz, W. (2001). „O dwóch podstawach intelektualizmu Sokratesa (Protagoras 351b-357e)”. Kwartalnik Filozoficzny, 29.1 (2001). 29-48.

Graf, F. (2002). La génese de la notion du mythe. W: Mitos en la literatura Griega arcaica y clásica, Madrid: Ediciones Clásicas. http://www.maicar.com/GML/020Contributors/FGGenese.html [18.01.2015].

Greek-English Lexicon (1883). H. G. Liddell, R. Scott (eds.). New York: Harper \& Brothers.

Guardini, M. L. (1987). Il mito di Elena. Testi di Euripide e Isocrate. Treviso: Edizioni Canova Treviso.

Hammer, S. (1921). O wplywie tragedii Eurypidesa Hippolytos na poezję hellenistyczna. Poznań: Gebethner i Wolff.

Jasionowicz, S. (2003). Intertekstualność w świetle badań nad wyobraźnia twórczą. W: Sosień, B. (ed.), Intertekstualność i wyobraźniowość. Kraków: Universitas.

Kane, S. (2002). „Miłość Fedry”. M. Semil. Dialog 3/2002. 57-75.

Klemczak, S. (2005). „Szaleństwa prób definiowania mitu”. Studia Religiologica. Zeszyty Naukowe Uniwersytetu Jagiellońskiego 38 (2005). 45-63.

Kowzan, T. (1998). Znak i teatr. Warszawa: Biblioteka Myśli Semiotycznej. 
Lehmann, H.-Th. (1999). Die Gegenwart des Theaters. In: E. Fischer-Lichte et al. (eds.), Transformationen: Theater der neunziger Jahre, Berlin: Verlag der Autoren, 1999. 13-26.

Lehmann, H.-Th. (2004). Teatr postdramatyczny. Przeł. D. Sajewska, M. Sugiera. Kraków: Księgarnia Akademicka.

Lévi-Strauss, C. (1955) “The structural study of myth". Journal of American Folklore 68.270 (1955). 428-444.

Lévi-Strauss, C. (1985). La poetière jalousie. Paris: Pion.

Markowski, M. P. (2006). Dekonstrukcja. W: A. Burzyńska. M. P. Markowski. Teorie literatury XX wieku. Podręcznik. Kraków: Znak. 361-380.

Merleau-Ponty, M. (1996). Widzialne i niewidzialne. Przeł. M. Kowalska, J. Migasiński, R. Lis, I. Lorenc. Warszawa: Fundacja Aletheia.

Merleau-Ponty, M. (2001). Fenomenologia percepcji. Przeł. M. Kowalska, J. Migasiński. Warszawa: Fundacja Aletheia.

Nancy, J.-L. (2002). Corpus. Przeł. M. Kwietniewska. Gdańsk: słowo/obraz terytoria.

Nussbaum, M. C. (2009). Therapy of Desire. Theory and Practice in Hellenistic Ethics. New Jersey: Princeton University Press.

Pavis, P. (1989). „Od tekstu do przedstawienia: trudny poród”. Przeł. M. Sugiera. Dialog 8/1998. $102-117$.

Pavis, P. (2011). Współczesna inscenizacja. Źródta, tendencje, perspektywy. Przeł. P. Olkusz. Warszawa: PWN.

Platon (2003). Państwo. Przeł. Wł. Witwicki. Kęty: Wydawnictwo ANTYK.

Racine, J. (2000). Phèdre. Classiques universels. Paris: Gallimard.

Racine, J. (2002). Fedra. Przeł. T. Boy-Żeleński. Kraków: Zielona Sowa.

Sarrazac, J. P. (ed.) (2007). Stownik dramatu nowoczesnego i najnowszego. Przeł. M. Borowski, M. Sugiera, Kraków: Księgarnia Akademicka.

Seneca, L. A. (1928). De ira. In: Moral Essays. Vol. I. Trans. J. W. Basore, Cambridge: Harvard University Press.

Seneca, L. A. (1990). Phaedra. M. Coffey, R. Mayer (eds.). Cambridge: Cambridge University Press.

Seneka, L. A. (1959). Fedra. Przeł. A. Świderkówna, BN II nr 118. Wrocław: Ossolineum.

Seneka, L. A. (1989). Dialogi. Przeł. L. Joachimowicz. Warszawa: IW Pax.

Seppilli, A. (1982). Poesia e magia. Torino: Giulio Einaudi editore.

Skarga, B. (1999). Tożsamość i różnica. Eseje metafizyczne. Kraków: Znak.

Sloterdijk, P. (2008). Krytyka cynicznego rozumu. Przeł. P. Dehnel. Wrocław: Wyd. Dolnośląskiej Szkoły Wyższej.

Sosień, B. (2003). Hipoteksty, teksty, mity, czyli o wspótistnieniu metod. W: B. Sosień (ed.). Intertekstualność $i$ wyobraźniowość. Kraków: Universitas.

Tasnádi, I. (2000). Fedra fitness. Przeł. J. Jarmołowicz, J. Czech. W: Kolizje. Antologia nowego dramatu węgierskiego. T. I. Wybór Patricía Pászt. Kraków: Panga Pank.

Ubersfeld, A. (2002). Czytanie teatru I. Przeł. J. Żurowska. Warszawa: PWN.

Wachowski, J. (1993). Dramat-mit-tradycja. O transtekstualności w polskiej dramaturgii wspótczesnej, Poznań: Acarus.

Wesołowska, E. (1991). Postaci w „,Medei” $i$,Fedrze” Seneki w perspektywie akcji oraz interakcji scenicznej. Poznań: Wydawnictwo Uniwersytetu Adama Mickiewicza.

Worthen, W. B. (2013). Dramat: między literatura a przedstawieniem. Przeł. M. Borowski, M. Sugiera. Kraków: Księgarnia Akademicka. 